\title{
Religious Education Using Deeniyat Method on Children of Streets and Dhu'afa People in The Aqidah Ujung Tanduk Area That is Vulnerable to Christianizated
}

\author{
Muhammad Nurul Fajri ${ }^{1}$, Iik Arifin Mansurnoor ${ }^{2}$, Sururin $^{3}$, Dede Rosyada ${ }^{4}$, \\ Ade Rina Farida ${ }^{5}$, Husni Rahim ${ }^{6}$ \\ \{muhamadnurulfajri@uinjkt.ac.id'1, iik.arifin@uinjkt.ac.id², sururin@uinjkt.ac.id³, \\ dede.rosyada@uinjkt.ac.id ${ }^{4}$, ade.rinafarida@uinjkt.ac.id ${ }^{5}$, husni.rahim@uinjkt.ac.id\}
}

Postgraduate School of Syarif Hidayatullah State Islamic University of Jakarta, Indonesia ${ }^{123456}$

\begin{abstract}
The purpose of this article is to explain the learning methods applied by an educator to their students with a variety of Islamic Education Methods with the Deeniyat Method, and to discuss more deeply how the Deeniyat Method is implemented. The method is one of the strategies or methods used by the teacher in the learning process to be achieved, the more precise the method used by a teacher, the better learning will be. Islamic education is an absolute necessity to be able to implement Islam as willed by Allah. Deeniyat is an Intensive Religious Education Development Program for Children, Adolescents and Adults that lasts 1 hour every day with material tailored to the needs, abilities and psychology of children in memorizing, living and practicing their knowledge in everyday life to form Islamic Character. This Deeniyat method has been researched, tested and implemented in Indonesia since 2009. Then, it has begun to actively form the Pilot Deeniyat Madrasah accompanied by regular socialization and publication in 2011 under the Deeniyat Nusantara Foundation as the Center for System Development and Management of the Deeniyat Madrasah.
\end{abstract}

Keywords: education, method, Islam education, deeniyat method

\section{Introduction}

Learning is the most important element[1] in achieving educational goals[2]. If there is a decrease in the quality of education, then usually the first thing to evaluate is the component related to education[3], especially the teacher as the executor of learning[4]. Learning is the ability to manage operationally[5] and efficiently[5] the components related to learning to produce added value to these components according to applicable norms/standards [6]

In a learning system, the role of a teacher is crucial[7]. In an Arabic expression it is stated, "Ath-thoriqatu ahammu minal maadah, wal mudarrisu ahammu min kulli syai" (The method or method of learning is more important than learning material and the teacher is more important than everything)[8]. This expression implies that a teacher must master the learning material to be delivered[9]. The task of a teacher at this time to educate students[4] in conditions of weakening morality[10] and national cultural character[11] would be even harder. Because education must be carried out in an integrated manner[12] which is a 
conscious[13], structured[14], programmed[15], and systematic effort[16] aimed at forming humans who possess national cultural characteristics.[17]

As professionals, teachers are not only required to master the subject matter[4] but are also skilled in assisting [18] and guidance to students to be able to develop their potential[19]. Teachers are also expected to be able to act as innovators[20] and become agents of renewal, so teachers need to have adequate insights about various educational technology innovations[21] that have and may be developed at the educational level. In this process, teachers are needed to set an example[4], build will, and build the potential and creativity of students[7]. The implication of this principle is the paradigm shift in the education process[22], namely from the teaching paradigm to the learning paradigm[22].

Better than that, the mastery of learning methods by a teacher has even more importance [4] and determines the success of a learning process than just mastery of the material[4]. To achieve optimal learning outcomes an appropriate learning strategy is needed[23] so those goals can be realized. A learning strategy is a plan that contains a series of activities designed to achieve learning objectives[23]. Lots of learning strategies that can be selected by a teacher in the learning process[24], such as problem-based learning[25], cooperative learning[26], contextual learning[27], learning by discovery[28], and so forth.

In general, learning methods[29] are ways that can be taken to facilitate the achievement of educational goals[7]. Keep in mind, that the method is closely related to the approach used.

Of the many educational methods offered by some education experts[29], not all of them can be applied to every lesson. Therefore, every educator should first be able to consider what methods are appropriate to use[12], which can influence learning outcomes in a direction that is better and relevant to the subject matter to be delivered. Also, the use of various methods is a consideration for each teacher[7], to increase children's interest in learning.[4]

Furthermore, if the word method is associated with Islamic education, it can carry meaning as a way to instill religious knowledge in a person[30] so that it can be seen in the person of the target object, namely the Islamic person[30]. Also, Islamic education methods can be interpreted as a way to understand, explore, and develop Islamic teachings[20], so that they continue to develop by the times.

In Islamic education, the method has a very important position to achieve the goal[29], because it becomes a means of meaningful subject matter arranged in the education curriculum[31] so that students can understand or be absorbed into functional understandings of their behavior. In Islamic education, an appropriate method if it contains intrinsic and extrinsic values is in line with the subject matter and can be functionally used to realize the ideal values contained in the goals of Islamic education[30]. Between methods, curriculum (material) and the objectives of Islamic education contain ideal and operational relevance in the educational process[31].

\section{Understanding Islamic Education Methods}

The method is one of the strategies or methods used by the teacher in the learning process to be achieved[29], the more precise the method used by a teacher, the better the learning will be[4]. The method comes from the word "methods" in Greek which means way or way. The method is comprehensive planning to present language learning materials 
regularly[29], there is no one contradictory part, and all of them are based on a certain approach. An axiomatic approach is an approach that has clear truths, while the method is procedural that is the approach by applying steps.[32]

The educational method is a method or path taken to achieve the objectives in educational activities[29]. Armai Arief in the Big Indonesian Dictionary stated that "the method is a systematic way of working to facilitate the implementation of an activity to achieve the specified goals."[33] With the method, the achievement of objectives in an educational activity will be more systematic and directed. [29]

The Islamic education can be explained as a conscious effort to direct the growth and development of children[30] with all the potential given by God to him to be able to carry out the mandate and responsibility as the caliph of God on earth in his service to Allah.[34]

Islamic education is an absolute necessity to be able to implement Islam[30] as desired by God. Based on this meaning, Islamic education prepares human beings to carry out the mandate that is given to them. This means the sources of Islam and Islamic education are the same, namely the most important, the Qur'an[8] and the Sunnah of the Apostles.[35]

The method of Islamic education in its application has much to do with educational insights whose sources are in the Qur'an and Al Hadith[30]. The method of Islamic education is very effective in fostering the personality of students[36] and motivating them so that the application of this method allows tens of thousands of believers to open people's hearts to receive divine guidance and concepts of the forerunners of Islam.[37]

\section{3 'Iqro Method}

'Iqro comes from Arabic which means "read"[38]. If the word 'iqra is combined with a method, it means a neatly arranged (systematic) or neat way to achieve the goal, in this case, is being able to read the Qur'an fluently and in tartil.[39]

Teaching occurs when there are teachers and students, educational tools and there are definite goals[12]. The teacher teaches the material while students/students will hear and learn it again. [38]

The iqro 'method in practice does not require a variety of tools, because it is emphasized in its reading (reading the letters of the Qur'an fluently)[38]. Direct reading without spelling. This means that the names of hijaiyah letters are introduced by active student learning (CBSA) and are more individualized.[40]

The purpose of teaching Iqro 'is to prepare students to be a qur'ani generation that is a generation that loves the Qur'an, commitments to the Qur'an, and make it a reading and daily view of life. [8]

\section{Deeniyat Method}

The Deeniyat method is a method adapted from the Islamic education curriculum in Mumbai, India. But it only began to enter Indonesia around the end of 2009. [41]Through KH Ahmad Harun Ar-rasyid Bandung, which was originally requested by Shaykh Maulana Ahmad lat, to translate the learning modules in the Deeniyat method from his native language into Indonesian. Initially, the Deeniyat method was planned to be developed in Semarang. But for several reasons, finally, the Deeniyat method was developed by KH Ahmad Harun 
Arrasyid Bandung in the Bandung area. Until now, the Deeniyat method is still in the stage of development and dissemination. Several times there have also been training and training for prospective teachers who want to use the Deeniyat method as a curriculum

Deeniyat is an Intensive Training Program for Religious Education for Children, Adolescents, and Adults that lasts 1 Hour every day with materials tailored to the needs, abilities, and Psychological of Children in memorizing, living, and practicing their knowledge in daily life to shape Islamic Character. This Deeniyat method has been researched, tested, and implemented in our beloved homeland since 2009[41]. Then it began to actively form a Pilot Deeniyat Madrasa accompanied by periodic Socialization and Publication in 2011 under the Deeniyat Nusantara Foundation as the Center for Deeniyat Madrasah Management and Madrasah Management.

Along with the development of time, deeniyat education programs have increasingly developed with innovations according to the needs of students. Even not only in madrassas or in mosques/prayer rooms, but nowadays it develops in street children on the side of the road, under the bridge, or places that are difficult to reach by most people. But unfortunately, the lack of socialization caused deeniyat methods not to be widely adopted by accredited educational institutions. For this reason, broader socialization needs to be done so that the deeniyat method can be known by the community.

\section{Deeniyat Method, Media for Creating regeneration of people}

In an organization, a cadre is a spearhead and the backbone of the continuity of an organization[42]. Not only were they expected from the organization's existence to be maintained, but it was also hoped that cadres would carry the mission of the organizational movement[43]. The meaning of the cadre itself is a person or group of people who are fostered by a management body in an organization, both civil and military, who function as 'parties' and / or assist the main tasks and functions of the organization[44]. Bung Hatta once stated regeneration within the framework of nationality, "That regeneration is synonymous with planting seeds. To produce future national leaders, leaders in their time must plant."

From this, the general view of the regeneration of an organization can be mapped into two icons in general[45]. First, regeneration actors (subjects). And second, the regeneration target (object). For the first, the subject or cadre of an organization is an individual or group of people who are personified in an organization and its policies[46] that carry out the regeneration and continuity of organizational tasks.[45]

Because cadre is very important for an organization, it is necessary to do regeneration[43]. Cadre has the functions of production and regeneration. A good regeneration process will produce and print good cadres[42]. It has been clearly stated in the verse that the Prophet Muhammad was the best role model that Allah Almighty has ever sent to mankind[8]. In every act, there is nothing that cannot be taken into a valuable lesson. Prophet Muhammad as a messenger, as a leader in the family, as head of state, even as an educator or patron of his people.[47]

The cadres of Rasulullah SAW were born from a generation of Rabbani who was not only privileged with the breadth of knowledge[34] but also the strength of faith and piety, the straightness of logic and perspective, as well as the height of wisdom and morals[35]. These four points, if found in a believer, he has instilled the nature of bashirah in him[35]. These 
points should be instilled in the cadres within an organization if moreover, the organization is a missionary movement. [42]

The second point is exemplary, The regeneration process requires exemplary[46]. As exemplified by the Prophet, namely by doing what he said[35]. So the current condition of cadres, especially in the campus organization, we find that the results of cadre did not go well, in other words, cadres were not formed as expected, the cadres became obedient and carried out what he called for. If we compare it with the fact that when conducting regeneration, the subjects who carried out the regeneration (instructor or trainer or tutorial) already feel instilled the values that must be possessed by the cadres, the answer is quite simple, this is because the subjects who carry out the regeneration do not apply the values what he said to his cadres, instructors or trainers or tutors emphasize to cadres to implement the values of religiosity.[48]

The next point is systematic, the Messenger of Allah in carrying out regeneration is always organized and planned[35]. Because activity, in this case, is regeneration, if it is arranged properly and thoroughly it will produce maximum results. While at Arqam's house, the Messenger of Allah had made a plan for how he would educate or galvanize his friends, so, the companions not only sat quietly but the Prophet sallallaahu 'alaihi wa sallam gave each of them the tasks and burdens that must be carried out.[34]

Among the tasks of some of the friends was the reception of foreigners who came to Mecca to find clarity about the religion of Islam that began to spread outside of Mecca, this task was assigned to Ali ibn Abi Talib radhiyallahu 'anhu. This is illustrated by the story of Abu Dzar radhiyallahu 'anhu who came to Mecca in search of clarity about Islam, which was then invited by Ali ibn Abi Talib to confront the Apostle at the House of Arqam.[34]

\section{Various methods of Islamic education}

The issue of education arises along with the existence of man himself above the world[49] because human beings are homo educandum which means that human beings are essentially beings who also can and must be educated[50], also can and must educate. Thus, this statement expands the true meaning of education which up to now has been oriented towards the world of education.

The conditions mentioned above, currently many people have abandoned, and because they think that learning in the world of school is not the only factor that determines the style of one's life. The physical, social, and cultural environment that is always changing, requires people to continuously learn so as not to be out of date.[51]

\subsection{Majlis Taklim}

Non-formal educational institutions that hold Islamic studies[52]. This institution develops within the Muslim community in Indonesia both in Jakarta and in other regions. The naming of majlis taklim is more commonly found in Jakarta, especially among Betawi people, while in other areas it is better known as "Islamic Religious Studies". Although the word Majlis Taklim comes from Arabic, the term itself is not used in Arab countries/societies.[53] 
Etymologically, majlis taklim can be interpreted as a place to carry out the teaching or study of Islam. In its development, majlis taklim is no longer limited to a place of teaching but has become an institution or institution that organizes teaching or recitation of Islam.[52]

The majlis taklim deliberation throughout DKI Jakarta in 1980 has given a more definitive boundary on the meaning of majlis taklim[53]; that is an Islamic non-formal educational institution that has its curriculum, is organized regularly and regularly, and is followed by relatively many congregations and aims to foster and build polite and harmonious relations between humans and God, humans with each other, humans with the environment, in the context of fostering people who fear Allah SWT.[8]

\subsection{Teenage Mosque}

Mosque youth is a youth organization that is held in every mosque, that is, all Muslims who are puberty who live around the mosque[54]. In practice, this organization is filled by a group of people. Usually called an administrator who has the duties and responsibilities of each. Thus the relationship between the management and the division of tasks between them runs well and effectively[55]. But of course, the organization is not static but dynamically develops according to space and time.

Mosque youth is a mosque organization, which means a body consisting of mosque administrators who manage and manage mosques. The organization of this mosque is very important to maximize the function of the mosque as a place of worship and social. To realize a good mosque organization, of course, must be supported by human resources, skilled management, sufficient capital or funds, supporting tools and facilities, and the mental attitude of its members.[46]

Several activities are usually carried out by mosque youth, such as religious lectures, leadership training, motivation training, and so on. They also often handle religious events such as the commemoration of the Mawlid and Isra Mi'raj of the Great Prophet Muhammad, the commemoration of a Muharram, and the activities of nuzul al-Qur'an during the Holy Month of Ramadan.[54]

Thus the youth of the mosque including non-formal educational institutions that contribute a lot to Islamic education.[54]

\subsection{Pesantren Kilat}

Pesantren kilat (sanlat) referred to here are activities that are usually carried out during school holidays which are often held during the fasting month and, filled with various forms of religious activities such as, open together, religious study or discussion or certain books, tarawih prayer in congregation, tadarus al-Qur'an and deepening, and so forth[56]. This activity is a form of intensive activities carried out in a certain period which is followed in full by students for 24 hours or just a part of the time to train them to liven up the days and nights of the month of Ramadan with worship activities. What is certain is that the activities carried out here emulate what is done in pesantren in general both salaf and modern.

\subsection{Raudhatul Athfal}

Islamic educational institutions for children of preschool age, ie ages 4 to 6 years managed by the community with a duration of education of 1 or 2 years. The characteristic of this kindergarten can be seen from the efforts to develop faith and devotion intensively in the 
souls of students through the creation of a religious atmosphere in the classroom and the inspiration of all areas of development with Islamic teachings[57]. This institution has several names, such as Bustanul Atfal (Kindergarten) and Tarbiyatul Atfal (Kindergarten Education). The Muhammadiyah organization uses the term Bustanul Atfal Aisyiah, while in Nahdatul Ulama (NU) two names are used, namely Raudhatul Atfal Ma'arif NU and NU's Kindergarten.

Raudhatul Atfal curriculum is formulated in an integrated curriculum which is also called an integrated curriculum. An integration curriculum is a curriculum that knows no subject boundaries. Learning material is presented in the form of a unified whole and not separated. This means that all subject matter is presented in the form of a unit of learning activities. The integration curriculum has three forms, namely:[57]

Experience curriculum, which is an arrangement/preparation of program activities based on the experience of children/children's activities, such as playing, telling stories, traveling, and sightseeing.[58]

Social Function Curriculum (social function curriculum), which is the organization and preparation of program activities based on the lives of children involving social functions, for example, conservation, protection, religious, cultural, production, recreation, and creative activities.[59]

Child-Centered Curriculum (curriculum centered on children), which is the arrangement/preparation of program activities based on a child-centered approach.[60]

Education in Raudhatul Atfal does not recognize groupings of students based on ranking but the basis of age. Group A for students aged 4 years and group B for 5 years old. Education in Raudhatul Atfal does not recognize the existence of examinations, class stays, and graduation ceremonies for their students. The Raudhatul Atfal Institute is managed by the community in the form of a foundation or the like. [57]

\section{Conclusion}

In addition to formal Islamic educational institutions, non-formal Islamic educational institutions also contribute significantly to the development of Islamic education among Indonesian Muslims. Among several non-formal Islamic educational institutions that are very instrumental and continue to experience development and progress with their respective characteristics are the Pesantren Kilat, Majlis Taklim, Youth Mosque, and Raudhatul Athfal and the deeniyat program.

Pesantren Kilat, in general, activities held during the holy month of Ramadan for students at the elementary, junior, and senior high schools to fill in the blanks during the Ramadan holidays. Majlis taklim is an institution of study and guidance and for parents or certain groups and groups which are usually more dominated by mothers. Mosque adolescents play the role of mosque congregants who come from young people around the mosque which are one of the centers of Islamic da'wah. While Raudhatul Athfal is an institution that is specifically for pre-school children or before they enter primary school, to provide them with an initial understanding of Islamic and other knowledge. Deeniyat gave the role of street children to become dignified people. With the diversity of institutions, Indonesian society can wisely choose which institutions/programs are suitable for children, adolescents, and adults. The deeniyat program has its differences with a variety of education 
similar to pesantren, street people can experience education as well as other formal or nonformal institutions and even later will print cadres of people who are strong and dignified. 


\section{References}

[1] J. D. Karpicke and H. L. Roediger, "The critical importance of retrieval for learning," Science (80-. )., 2008, doi: 10.1126/science.1152408.

[2] C. Ames, "Classrooms: Goals, Structures, and Student Motivation," J. Educ. Psychol., 1992, doi: 10.1037/0022-0663.84.3.261.

[3] D. Adams, "Defining quality in education," Improv. Educ. Qual. Proj., 1993.

[4] D. N. Harris and T. R. Sass, "Teacher training, teacher quality and student achievement," $J$. Public Econ., 2011, doi: 10.1016/j.jpubeco.2010.11.009.

[5] S. B. Kaufman, C. G. DeYoung, J. R. Gray, L. Jiménez, J. Brown, and N. Mackintosh, "Implicit learning as an ability," Cognition, 2010, doi: 10.1016/j.cognition.2010.05.011.

[6] P. R. Pintrich and E. V. De Groot, "Motivational and Self-Regulated Learning Components of Classroom Academic Performance," J. Educ. Psychol., 1990, doi: 10.1037/0022-0663.82.1.33.

[7] M. Lunenberg, F. Korthagen, and A. Swennen, "The teacher educator as a role model," Teach. Teach. Educ., 2007, doi: 10.1016/j.tate.2006.11.001.

[8] Quran.com, The Noble Quran. 2016.

[9] W. J. McCaslin and J. Lowman, "Mastering the Techniques of Teaching," Teach. Sociol., 1985, doi: $10.2307 / 1318070$.

[10] D. Lapsley and R. Woodbury, "Moral-Character Development for Teacher Education," Action Teach. Educ., 2016, doi: 10.1080/01626620.2016.1194785.

[11] R. C. Richardson, H. Tolson, T. Y. Huang, and Y. H. Lee, "Character education: Lessons for Teaching Social and Emotional Competence," Child. Sch., 2009, doi: 10.1093/cs/31.2.71.

[12] L. Darling-Hammond, "How teacher education matters," J. Teach. Educ., 2000, doi: $10.1177 / 0022487100051003002$.

[13] D. A. Gruenewald, "Foundations of Place: A Multidisciplinary Framework for PlaceConscious Education," American Educational Research Journal. 2003, doi: $10.3102 / 00028312040003619$.

[14] B. DiCicco-Bloom and B. F. Crabtree, "The qualitative research interview," Medical Education. 2006, doi: 10.1111/j.1365-2929.2006.02418.x.

[15] Š. Hoskova-Mayerova and Z. Rosická, "Programmed learning," 2012, doi: 10.1016/j.sbspro.2011.12.141.

[16] D. Dicheva, C. Dichev, G. Agre, and G. Angelova, "Gamification in education: A systematic mapping study," Educ. Technol. Soc., 2015.

[17] R. Nash, "Bourdieu on Education and Social and Cultural Reproduction," Br. J. Sociol. Educ., 1990, doi: 10.1080/0142569900110405.

[18] J. Onrubia and A. Engel, "The role of teacher assistance on the effects of a macro-script in collaborative writing tasks," Int. J. Comput. Collab. Learn., 2012, doi: 10.1007/s11412-011-9125-9. [19] A. Van Leeuwen, J. Janssen, G. Erkens, and M. Brekelmans, "Supporting teachers in guiding collaborating students: Effects of learning analytics in CSCL," Comput. Educ., 2014, doi: 10.1016/j.compedu.2014.07.007.

[20] H. P. Putri, "Promoting The Learning Quality of Islamic Elementery School Through Constructive - Inovative Model," J. Educ. J. Educ. Stud., 2019, doi: 10.30983/educative.v4i2.1074.

[21] S. L. Tudor, "The Role of Multimedia Strategies in Educational Process," Procedia - Soc. Behav. Sci., 2013, doi: 10.1016/j.sbspro.2013.04.375.

[22] J. Mbarushimana, N. \& Kuboja, "A paradigm shift towards competency-based curriculum: The experience of Rwanda,” J. Dev. Stud., 2018, doi: 10.1080/00220388.2018.1453602.

[23] A. L. Strategy, "A learning strategy," Image Rochester NY, 2002.

[24] M. Fullan, "Change the terms for teacher learning," J. Staff Dev., 2007, doi: 10.1017/CBO9781107415324.004. 
[25] P. Learning, "Features of Problem-Based Learning," Winter, 2001.

[26] R. E. Slavin, "Cooperative Learning," Rev. Educ. Res., 1980, doi: $10.3102 / 00346543050002315$.

[27] S. L. Danver, "Contextual Teaching and Learning," in The SAGE Encyclopedia of Online Education, 2016

[28] D. Hammer, "Discovery learning and discovery teaching," Cognition and Instruction. 1997, doi: $10.1207 / \mathrm{s} 1532690 x$ ci1504 2.

[29] G. Gibbs, "A guide to teaching and learning methods," in Learning by Doing, 1988.

[30] Y. Waghid, "Islamic education," in International Encyclopedia of Education, 2010.

[31] Education Scotland, "What is Curriculum for Excellence?," Education Scotland, 2017.

[32] I. N. Herstein and J. Milnor, "An Axiomatic Approach to Measurable Utility," Econometrica, 1953, doi: $10.2307 / 1905540$

[33] Ensiklopedia Indonesia, "Ensiklopedia Indonesia," J. Adab., 2004.

[34] G. Downum and S. M. R. Bengalee, "The Life of Muhammad," Books Abroad, 1943, doi: $10.2307 / 40083214$

[35] A. Sabiq, N. Hasanuddin, A. Saipuddin, and J. Al-Yamani, Fiqh al-Sunnah. 2014.

[36] R. R. McCrae and P. T. Costa, "The Five Factor Theory of personality," in Handbook of Personality, 2008.

[37] P. M. Holt (Hrsg.), A. K. S. Lambton (Hrsg.), and B. Lewis (Hrsg.), "The Cambridge History of Islam," Verfassung R. und Übersee, 1971, doi: 10.5771/0506-7286-1971-2-224.

[38] G. E. Muhammad, "Iqra," Writ. Commun., 2015, doi: 10.1177/0741088315590136.

[39] C. A. Windarsih, "AN IMPLEMENTATION OF PARTICIPATIVE IQRO METHOD IN THE ORIENTED OF AL-QURAN EDUCATION CENTER ON THE PURPOSE OF LEARNING GOAL AND OBJECTIVES FOR EARLY CHILDREN," Empowerment, 2019, doi: 10.22460/empowerment.v8i1p25-29.1146.

[40] A. Lumpkin, R. M. Achen, and R. K. Dodd, "Student perceptions of Active Learning," Coll. Stud. J., 2015.

[41] Galih, "Deeniyat," 2017. https://deeniyatnusantara.com/2017/06/04/apa-itu-deeniyat/ (accessed Aug. 16, 2020).

[42] D. Ulrich and N. Smallwood, "What is leadership?," Adv. Glob. Leadersh., 2012, doi: 10.1108/S1535-1203(2012)0000007005.

[43] J. P. Wanous, A. E. Reichers, and J. T. Austin, "Group \& Organization Management," Cynicism about Organ. Chang. Meas. Antecedents, Correl., 2000, doi: $10.1177 / 1059601100252003$.

[44] A. Gregory Stone, R. F. Russell, and K. Patterson, "Transformational versus servant leadership: A difference in leader focus," Leadersh. Organ. Dev. J., 2004, doi: 10.1108/01437730410538671.

[45] D. S. Pugh, D. J. Hickson, C. R. Hinings, and C. Turner, "Dimensions of Organization Structure," Adm. Sci. Q., 1968, doi: 10.2307/2391262.

[46] J. R. Galbraith, "Designing the innovating organization," Organ. Dyn., 1982, doi: 10.1016/0090-2616(82)90033-X.

[47] J. Tolan, "The Lives of Muhammad," Islam Christ. Relations, 2016, doi: 10.1080/09596410.2015.1090726.

[48] A. Bryman, "Effective leadership in higher education: A literature review," Studies in Higher Education. 2007, doi: 10.1080/03075070701685114.

[49] L. Urrieta, "Figured worlds and education: An introduction to the special issue," Urban Review. 2007, doi: 10.1007/s11256-007-0051-0.

[50] E. Ingleby, "Research methods in education," Prof. Dev. Educ., 2012, doi: 10.1080/19415257.2011.643130.

[51] R. Inglehart and W. E. Baker, "Modernization, cultural change, and the persistence of traditional values," Am. Sociol. Rev., 2000, doi: 10.2307/2657288.

[52] Z. Abidin, "MAJLIS TA'LIM (ISLAMIC FORUM) AND HARMONIZING INTER FAITH COMMUNICATION," Inject (Interdisciplinary J. Commun., 2019, doi: 10.18326/inject.v4i1.115- 
136.

[53] A. A. Safei, "Development of islamic society based on majelis ta'lim: A study of the shifting role of the majelis ta'lim in west java," Am. J. Appl. Sci., 2016, doi: 10.3844/ajassp.2016.947.952.

[54] A. H. Tamuri, M. F. Ismail, and K. A. Jasmi, "A New Approach in Islamic Education: Mosque Based Teaching and Learning," JIAE J. Islam. Arab. Educ., 2012.

[55] E. R. Kismawadi, U. D. Al Muddatstsir, and T. Sawarjuwono, "Accountability and Innovative Financial Reporting To the Mosque," Int. J. Organ. Innov., 2018.

[56] M. A. F. Rozi, "Implementation of Prophetic Education in Islamic Boarding School (Pesantren)," Edukasi, 2018.

[57] S. Muyasaroh, "Penjaminan Mutu di Raudhatul Athfal," Ta'allum J. Pendidik. Islam, 2016, doi: 10.21274/taalum.2016.4.2.317-334.

[58] J. Dewey, "Experience and education," Educ. Forum, 1986, doi: $10.1080 / 00131728609335764$.

[59] M. Green, "The Social Function of Education," Coll. English, 1976, doi: 10.2307/375925.

[60] K. Weiler and K. Weiler, "The Child and the Curriculum," in Democracy and Schooling in California, 2011. 